\title{
原子炉出力向上に関する技術検討評価の 結果について
}

「原子炉出力向上に関する技術検討評価」特別専門委員会 最終報告

\section{はじめに}

原子炉出力向上とは，既存の原子力発電プラントの安 全を損なうことなく，原子炉の定格熱出力を上げて発電 出力を 1 〜 $20 \%$ 程度増加することである。これは, 地球 温暖化対策およびエネルギー安全保障の観点から，有利 な原子力発電の優れた特性を活かし, 原子力発電プラン トを有効に活用しようとするものである。すでに米国や 欧州では30年以上前から合わせて約 160 件に及ぶ多数の 原子炉出力向上が認可, 実施され, これらの出力向上に よって増加した発電容量は $100 万 \mathrm{~kW}$ 級発電所約7.6基 分に相当する。

仮に，国内すべての既設プラントが $5 \%$ の出力向上を 実施すれば，約 250 万W $\mathrm{kW}(100$ 万 $\mathrm{kW}$ 級の約 2.5 基分)の 電力を生み出すことができ, これは, 二酸化炭素の排出 量削減の観点からも無視できない量である。

米国においては，原子力規制委員会 (Nuclear Regulatory Commission ; NRC) が原子炉出力向上審査の定型化 と期間短縮のため, 原子炉出力向上を次の 3 つの型式に 分類している。

（1）測定精度改善型 (Measurement Uncertainty Recapture : MU)

原子炉出力はおおむね $2 \%$ 以下の増加であり，原子 炉出力の算定に使用される給水流量計の計測不確かさ を超音波流量計の採用によって改善することにより， 安全解析で考慮される原子炉出力の計測誤差などの程 度 (原子炬出力計算の不確定性)を減らすことで対応す る。

Technical Study on Nuclear Reactor Safety Assessment for Power Uprstes : Koji OKAMOTO, Hirosige KIKURA, Akira YAMAGUCHI, Kaichiro MISHIMA, Naoto SEKIMURA. (2008年 8 月 5 日 受理)
「特別専門委員会」

東京大学 岡本孝司，東京工業大学 木倉宏成， 大阪大学 山口 彰

\section{「講評寄稿」}

京都大学 三島嘉一郎，東京大学 関村直人

\section{(2) ストレッチ型 (Stretch:S)}

原子炬出力 $7 \%$ までの増加であり, 大きな設備改造 を伴わずにプラント性能の範囲で害施する。

(3) 設備拡張型 (Extended:E)

原子炉出力 $20 \%$ 程度までの増加であり, 主要機器の 改造を実施する。

また，米国では特に一般規制ガイドラインに基づき， 原子炉出力向上の際にも確率論的リスク評価が行われて おり，E型出力向上(約20\%程度増) プラントのリスク評 価の結果では, 出力向上前後でのリスク増加量は小さ く, 許容基準を満足しており, 従来と同様に，安全性は 確保されることが示されている。

欧米と同型の原子力発電プラントを有する日本におい ても，安全に原子炉出力向上を実施することは欧米の実 績からも可能と考えられるが，本特別専門委員会は，こ うした欧米の状況も踏まえ，MU 型と $\mathrm{S}$ 型， $\mathrm{E}$ 型の出力 向上について技術検討評価を行ったので，その結果につ いて以下に紹介する。

(岡本孝司)

\section{I ．MU 型出力向上における超音波流量計}

原子炉出力は, 給水流量とエンタルピー上昇の積を取 ることで求められるが, 給水流量の計測には比較的大き な不確かさを含んでいる。このため, 原子炉の安全解析 では，この不確かさ(約 $2 \%$ )を考慮して，102\%出力で の解析が行われている。もし, 給水流量の計測不確かさ を，例えば1\%以下に抑えることができれば，すでに102 \%で安全が確認されているので，101\%で運転を続けて も安全は担保される。つまり, 給水流量の計測不確かさ を低減することで，安全を確保したまま，原子炉出力を 向上できることになる。この方法を MU 型原子炉出力 向上と呼び，すでに米国とスペインで導入されている。 
計測不確かさの小さな流量計としては，超音波流量計が 用いられている。

\section{1. 検討対象の超音波流量計}

米国で MU 型原子炉出力向上に用いられている超音 波流量計は，Chordal 型(伝播時間差式配管一体型), Crossflow 型 (相関時間差式)の 2 種類がある。それに加 えて，給水流量の管理・監視用途に実績のある External 型 (伝播時間差式配管外付型)という型式もある。

これらの流量計に対する日本国内の実機適用性試験, 米国規制当局における審査資料や発電所での実績デー夕 等の情報を基に，3 種類の超音波流量計に対して，技術 的にその不確かさを評価するとともに，更なる実証試験 の必要性などについて，学術的に検討・審議を行った。 第 1 表に検討対象とした 3 種類の流量計をまとめて示す。

\section{2. 検討・審議の視点}

流量の計測不確かさを議論する際，計測しようとして いる流体の慣性力や粘性力の影響を考慮する必要があ る。また，これらの影響を考慮する際には，一般的にレ イノルズ数という慣性力と粘性力の比を表す無次元パラ メータが用いられる。原子力プラントでは高温の水が大 量に流れているため, 実機ではレイノルズ数は約 $2 \times 10^{7}$ 程度になる。一方，流量計の校正試験で利用される実流 量試験装置では，流量 $(\mathrm{kg} / \mathrm{s})$ 自体は実機と等しいが,
レイノルズ数は約 $5 \times 10^{6}$ と小さい。このレイノルズ数 の違いが計測不確かさに与える影響について検討を行う 必要がある。また，校正試験では，実流量試験による実 測值と超音波流量計の計測值の比として校正定数を求め ている。この校正定数は，Chordal 型および External 型ではプロファイルファクタ (PF)，Crossflow 型では流 速分布補正係数 $(\mathrm{VPCF})$ と呼ばれる。

本検討では，不確かさ評価の対象として下記項目につ いて，実流量試験デー夕および実機デー夕を用いて評価 した。

(1) 校正定数 $(\mathrm{PF} \cdot \mathrm{VPCF})$

（2）流速分布への影響因子(レイノルズ数，流量計上 流の流体擾乱要素，配管内面の粗さ)

(3) レイノルズ数および温度・圧力の外挿性

（4）信号の SN 比(信号対ノイズ比)の管理

(5) 流量計の個体差

さらに，流量計の不確かさ・機能維持の方法として， 保守点検内容，自己診断機能等についても審議した。

以下に，それぞれの型式ごとに，計測不確かさに対す る評価結果を示す。

\section{Chordal 型超音波流量計}

Chordal 型 ( 8 測線)では, 米国の ARL (Alden Research Laboratory) 試験設備において，実機における流量計の 上流側配管形状を模擬した試験装置を用いて常温実流量

第 1 表 超音波流量計型式

\begin{tabular}{|c|c|c|c|}
\hline 型式 & Chorda1型 & External型 & Crossflow型 \\
\hline 概要図 & $\Rightarrow \frac{\pi}{x^{\pi}}$ & $\Rightarrow$ 流れ & 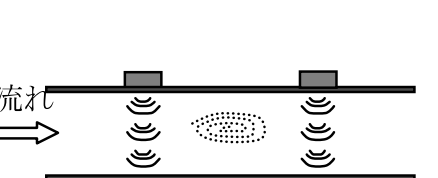 \\
\hline 計測方式 & 伝播時間差式配管一体型 & 伝播時間差式配管外付型 & 相関時間差式 \\
\hline 計測原理 & $\begin{array}{l}\text { 下流から上流への超音波伝播 } \\
\text { 時間と, 上流から下流への超 } \\
\text { 音波伝播時間との差が, 配管 } \\
\text { 内流速に比例することを利 } \\
\text { 用。配管内の平行 } 4 \text { 測線また } \\
\text { は } 8 \text { 測線上の線平均流速より } \\
\text { 流量を求める。 }\end{array}$ & $\begin{array}{l}\text { 下流から上流への超音波伝播 } \\
\text { 時間と, 上流から下流への超 } \\
\text { 音波伝播時間との差が, 配管 } \\
\text { 内流速に比例することを利 } \\
\text { 用。配管直径上の超音波伝播 } \\
\text { 経路の線平均流速を校正定数 } \\
\text { (プロファイルファクタ)で補 } \\
\text { 正することにより流量を求め } \\
\text { る。 }\end{array}$ & $\begin{array}{l}\text { 発信した超音波性状が配管内 } \\
\text { の渦と作用して変調すること } \\
\text { を利用。上流と下流の } 2 \text { 点で } \\
\text { 変調波の相互相関をとり, 渦 } \\
\text { の移動速度から流量を求め } \\
\text { る。 }\end{array}$ \\
\hline $\begin{array}{c}\text { 計測精度 }(2 \sigma) \\
(\text { メーカ公称) }\end{array}$ & $\pm 0.3 \sim 0.5 \%$ & $\pm 1.0 \%$ & $\pm 0.3 \sim 0.5 \%$ \\
\hline
\end{tabular}


試験(レイノルズ数： $５ \times 10^{6}$ )を実施し，ここで得ら れた校正定数 PFを $2 \times 10^{7}$ の高いレイノルズ数領域ま で外挿することによって実機相当の校正定数 PF を決定 するとともに，メーカが独自に確立した不確かさの評価 手法を用いることによって, 実機の質量流量計測不確か さがェ $0.28 \%$ であると評価している。

Chordal 型は, 直接流体に接した 8 測線データにより 計測していること, 校正定数 PF のレイノルズ数依存性 が大きくないこと, 流速分布の変動を比較的捕らえやす いこと, という特徴から, 校正定数 PF に関するレイノ ルズ数の外捚性は比較的高いと判断した。このことか ら, MU 型原子炉出力向上に利用できる計測不確かさを 有する可能性が高いと考える。なお，レイノルズ数の外 挿性をより詳細に確認するため, 高レイノルズ数領域で の試験を行い，日本国内だけではなく，世界中の原子力 プラントに対して，デー夕を提示することは意味がある と考える。

\section{External 型超音波流量計}

External 型ではChordal 型と同様に，米国の ARL (Alden Research Laboratory) 試験設備において, 実機 に打ける流量計の上流側配管形状を模擬した試験装置を 用いて常温実流量試験(レイノルズ数：〜 $5 \times 10^{6}$ ) を実 施し，ここで得られた校正定数 PFを $2 \times 10^{7}$ の高いレ イノルズ数領域まで外挿することによって実機相当の校 正定数 PF を決定するとともに, メーカが独自に確立し た不確かさの評価手法を用いることによって，実機の質 量流量計測の不確かさがさ1.0\%であると評価してい る。また整流装置下流4-12 D の位置に設置することで, 流速分布変化の影響を極小化する工夫がなされている。

External 型は直径軸上の 1 測線のみにて計測してい るため, 流速分布に関する情報量が少ないことが弱点で ある。また，配管外部から超音波信号を送受信している ことからノイズの影響を受けやすいため，ノイズに起因 して計上する不確かさの割合は Chordal 型に比較して 大きくなる傾向にあるが，適切な計測手順でノイズを実 機条件にて計測し不確かさを評価することが可能と考え られる。よって, MU 型原子炉出力向上に利用するため には，たとえ不確かさが $1.0 \%$ あっても，高レイノ ルズ数領域での試験を実施し，外捚性を確認することが 推奨される。

\section{Crossflow 型超音波流量計}

Crossflow 型の校正定数 VPCF は, 米国の実機デー夕 ならびに検定試験データからレイノルズ数に関連したパ ラメータの 1 次関数でフィッティングでき, 高レイノル ズ数領域での不確かさについて $0.25 \%$ 以内であること が説明可能であると，メーカは主張している。

Crossflow 型は，実機プラントの100\%流量条件にて
各系統の超音波流量計および差圧式流量計の流量指示值 を比較し，それぞれの計測值は時間変動を含めてよく一 致していることを確認した。しかし, 差圧式流量計の計 測不確かさは超音波流量計の計測不確かさと比べて大き いため, VPCF の不確かさ $(0.25 \%)$ を保証するために は，より精度の高い試験を行うことが望ましいと考え る。よって, MU 型原子炉出力向上に利用するためには, たとえ不確かさが $0.25 \%$ あっっても高レイノルズ数領 域での試験を実施し，外挿性を確認することが推奨され る。

なお，2008年 9 月に, NRC も Crossflow 型に関して, 試験設備で校正した結果を実機に適用する場合の不確か さ評価が不完全である等の技術的課題を挙げ，この課題 の解決を NRC が認めるまで, Crossflow 型超音波流量 計による MU 型原子炉出力向上の認可を中止するとの 見解”が出された。

\section{6. $\mathrm{MU}$ 型出力向上の関連事項}

$\mathrm{MU}$ 型出力向上に用いる超音波流量計の評価に関連し て，検討した事項をまとめる。

・本検討においては, 実機の不確かさを見積もるため に, 米国機械学会 (ASME) 方式の評価手法を用いて 検討を実施した。不確かさ評価に関する研究は日々 進歩しており, 国際標準化機構(ISO)ベースの評価 手法や, 設置場所と検定場所の違いなどの差を補正 するファシリティファクタなどの検討も進んでい る。今後, 技術の進歩に合わせて, 合理的に判断が 可能な不確かさ評価の標準的手法の確立が望まれ る。

· (独) 産業技術総合研究所には, 世界唯一の高レイノ ルズ数流量試験装置 ${ }^{2}$ (レイノルズ数: $\sim 1.7 \times 10^{7}$ ) があり，この有効利用が期待される。

・日本発の新しい超音波式の流量計として開発が進め

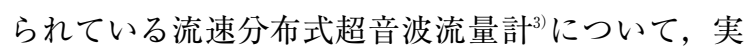
用化を進めることを期待する。

- 原子力安全委員会が策定している ECCS 性能評価 指針などでは, 明示的に定格熱出力の $102 \%$ \%回 らない出力で評価することを要求している。不確か さが低隇できれば，この $102 \%$ という数字も合理的 に変更を行う必要があると考えられる。

（木倉宏成）

\section{II . $\mathrm{S}$ 型, $\mathrm{E}$ 型出力向上について}

次に, $\mathrm{MU}$ 型よりも出力向上量の大きい $\mathrm{S}$ 型ならびに $\mathrm{E}$ 型原子炉出力向上について述べる。

\section{1. 出力向上に伴い安全上評価すべき項目の抽出} 我が国において出力向上を計画する場合, 基本設計段 
階で安全上評価すべき項目やその対応についてどのよう に検討したらよいか検討する。以下に，その考え方や検 討結果について述べる。

（1）どのように検討するか

出力向上における安全上評価すべき項目の検討は, 我 が国の原子炉施設安全審査のプロセスがベースとなる。 ここで注意すべきは次の 2 点である。 1 点目は， $\mathrm{S}$ 型, $\mathrm{E}$ 型出力向上はプラント全体に影響を及ぼす可能性があ るため，検討においては安全上評価すべき項目を網羅的 に抽出することが重要であること， 2 点目は，出力向上 は既設の運転プラントで実施することから，プラントの 経年変化の観点も考慮すべきであること，である。

まず，実際に出力向上において安全上評価すべき項目 やその対応について机上検討する。検討にあたっては， 我が国の既設軽水炉 (BWR，PWR)を対象に，出力増加 割合は欧米での実績と同程度と想定し, 我が国で利用可 能な技術的知見などを活用することを前提とした。具体 的手順は以下の通り。

（1）安全上評価すべき項目を網羅的に抽出することを 目的に，出力向上に伴い変化するプラントパラメー 夕と主要系統設備への影響を検討, 分類する。

（2）（1）の影響分類をもとに，原子炉設置許可申請書に 記載されている全項目について，出力向上による影 響の有無を確認する。

（3）（2）で「影響あり」とした項目について，「安全上評 価すべき項目」を抽出する。抽出された評価項目は, $「[\mathrm{a}]$ 安全評価に係る項目」と，「[b]設備への影響を 評価すべき項目」に分類する。

（4）「[a]安全評価に係る項目」は，評価方法および判 断基準を明確にし，出力向上に係る影響を評価・考 察する。「[b]設備への影響を評価すべき項目」は， 出力向上による影響と対応方針を検討する。

(2)で評価のベースを原子炉設置許可申請書とするの は，本図書がプラントの基本設計段階において安全性確 保の観点から安全審査に用いられる指針類を踏まえて作 成するものであり，安全性に関連したプラント設備に関 して網羅的に記載された図書であることによる。なお， 原子炉設置許可申請書の中で，安全性の評価に関連する 内容は添付書類八，九，十であるため，実質的には評価 対象は添付書類八，九，十の全項目となる。

\section{（2）どのような結果が得られたか}

前述の手順に従って出力向上の影響を検討すると，原 子炉設置許可申請書記載項目のうち，「安全上評価すべ き項目」はBWR 125項目，PWR 120項目の合計245項目 が挙げられる。

このうち，「[a]安全評価に係る項目」に分類されるの は，燃料被覆管温度，反応度停止余裕，周辺公衆線量評 価, 非常用炉心冷却設備の冷却能力などである。抽出さ れた項目に対して，その評価方法を整理・検討した結
果，出力向上条件が現行の評価方法(計算コード)の適用 範囲内であれば，現行の評価方法は有効である。また， 判断基準についても，現行の判断基準はプラント仕様に 依存しないため，出力向上条件でも適用できる。すなわ ち，現行の評価方法を用いて出力向上条件で評価を行 い，現行の判断基準を満足すれば，安全性は確認するこ とができるといえる。さらに, 現在開発中の改良手法も， 将来的には評価方法として適用することも有効である。 なお，現行設備において判断基準を満足しない場合は， 判断基準を満足できるように設備改造(仕様の変更)で対 応することも可能である。

また，「[b]設備への影響を評価すべき項目」のうち， 「流れ加速型腐食による配管減肉への影響」, 「流れ誘起 振動に起因した振動疲労の影響—BWRの蒸気乾燥 器」,「中性子照射脆化への影響」について検討したが， これらは現在実施されている保全管理で対応可能であ る。その他の項目についても，設計，保全管理，運用管 理を適切に実施することによりプラントの安全性を保つ ことができる。

\section{2. 安全評価への影響について}

\section{（1）どうやって影響評価を行ったか}

ここでは，「[a]安全評価に係る項目」のうち，安全性 を確保する上で重要な安全評価審査指針に定められた評 価事象に対し，(1)出力向上において注目すべき評価項目 を確認すること, (2)出力向上後も安全性を確保できる見 通しを得ることを目的に，BWR/PWR 代表プラントに おける出力向上に係る影響を定量的に評価・考察する。 安全評価審査指針で評価の対象としている項目は第 2 表 の通りである。

出力向上の影響評価は，概略評価と解析評価の 2 段階 に分けて行う。まず概略評価では，各評価項目に対する 出力向上の影響を考察し，以下のように分類する。

分類 $\mathrm{A}$ ：出力向上の影響が軽微な項目

分類 B : 出力向上の影響を比較的容易に推測できる項 目

分類 C：出力向上の影響を概略評価では容易に推測で きない項目

次にCに分類された項目は，概略評価では影響を容 易に推測できない項目であり，出力向上時に注目すべき 項目と考え, 判断基準に対して最も厳しい事象を解析評 価する。なお，これら評価にあたっては，以下を主要な 前提条件とする。

(1) 対象プラントは BWR 5 代表プラント $(9 \times 9$ 型 燃料装荷 $),$ PWR 代表 3 ループプラント $(17 \times 17$ 型 燃料装荷)とする。

(2) 出力向上量は, BWR が $7 \%$ (米国における出力 向上分類のストレッチ型相当)，PWRが $9 \%$ (米国 Beaver Valley-1/2での設備拡張型出力向上の実績 
第 2 表 安全評価指針における評価対象項目

\begin{tabular}{|c|c|c|}
\hline & BWR & PWR \\
\hline \multirow{4}{*}{$\begin{array}{l}\text { 運 } \\
\text { 軽 } \\
\text { 異 } \\
\text { 常 } \\
\text { な } \\
\text { 過 } \\
\text { 蔗 } \\
\text { 変 }\end{array}$} & MCPR & 最小 DNBR \\
\hline & 表面熱流束 & 燃料中心温度 \\
\hline & 燃料エンタルピ & 燃料エンタルピ \\
\hline & $\begin{array}{l}\text { 原子炉圧力 (原子炉冷却材 } \\
\text { 圧力バウンダリーにかか } \\
\text { る圧力) }\end{array}$ & $\begin{array}{l}\text { 原子炉圧力 (原子炉冷却材 } \\
\text { 圧力バウンダリーにかか } \\
\text { る圧力) }\end{array}$ \\
\hline \multirow{8}{*}{$\begin{array}{l}\text { 事 } \\
\text { 故 }\end{array}$} & \multirow{2}{*}{ 炉心冷却性能 (PCT/ECR) } & 炉心冷却性能 (PCT/ECR) \\
\hline & & 炉心冷却性能(最小 DNBR) \\
\hline & 原子炉圧力 (原子炉冷却材 & 原子炉圧力 (原子炬冷却材 \\
\hline & $\begin{array}{l}\text { 圧力バウンダリーにかか } \\
\text { る圧力） }\end{array}$ & $\begin{array}{l}\text { 圧力バウンダリーにかか } \\
\text { る圧力） }\end{array}$ \\
\hline & 燃料エンタルピ & 燃料エンタルピ \\
\hline & 格納容器内圧力 & 格納容器内圧力 \\
\hline & 周辺公衆の受ける線量 & 周辺公衆の受ける線量 \\
\hline & 格納容器内可燃性ガス濃度 & 格納容器内可燃性ガス濃度 \\
\hline
\end{tabular}

MCPR：最小限界出力比, DNBR：限界熱流束比, PCT : 燃料被 覆管最高温度, ECR : 局所的最大ジルコニウム水反応量
と同程度)とする。

(3) 定格運転時の原子炉圧力および炉心流量 (BWR)/

1 次冷却材流量 $(\mathrm{PWR})$ は現行と同じとする。

\section{（2）BWR の評価結果}

(a) 出力向上において注目すべき項目は何か

代表 BWR プラントを対象に, 現行評価(出力向上前) の結果を参考に，安全評価の全事象を対象として，現行 手法をべースに評価項目ごとに出力向上に係る安全評価 への影響を概略評価する。概略評価の結果を第 3,4 表 に示す。概略評価結果は, 前述の出力向上の影響の程度 による分類で，以下のように整理することができる。

分類 A：表面熱流束, 燃料エンタルピ

分類 B：周辺公衆に対する線量

分類 $\mathrm{C}: \mathrm{MCPR}$, 原子炬圧力, $\mathrm{PCT} / \mathrm{ECR}$, 格納容器 内圧力, 格納容器内可燃性ガス濃度

以上より，BWRの安全評価において出力向上時に注 目すべき項目は, 分類 C の MCPR, 原子炉圧力, $\mathrm{PCT} /$ $\mathrm{ECR}$, 格納容器内圧力および格納容器内可燃性ガス濃 度である。

第 3 表 運転時の異常な過渡変化に対する概略評価結果 (BWR)

\begin{tabular}{|c|c|c|c|}
\hline $\begin{array}{l}\text { 評価項目 } \\
\text { (）内は判断基準 }\end{array}$ & $\begin{array}{l}\text { 判断基準に対して } \\
\text { 最も厳しい事象 }\end{array}$ & 出力向上の影響 & 分類 \\
\hline $\operatorname{MCPR}(\geqq 1.07)$ & $\begin{array}{l}\text { 負荷の喪失(発電機負荷 } \\
\text { 遮断バイパス弁不作動) }\end{array}$ & $\begin{array}{l}\text { 過渡時のボイド反応度印加割合が増加するため, MCPR 低下量 } \\
(\Delta \mathrm{MCPR}) \text { が大きくなることが考えられる。 }\end{array}$ & $\mathrm{C}$ \\
\hline 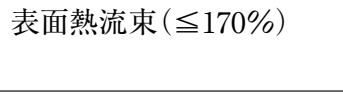 & $\begin{array}{l}\text { 出力運転中の制御棒の異 } \\
\text { 常な引抜き }\end{array}$ & $\begin{array}{l}\text { 初期值の熱的状態 (最大線出力密度), 制御棒引抜阻止信号の設定 } \\
\text { 值は変わらないため, 影響は軽微。 }\end{array}$ & $\mathrm{A}$ \\
\hline $\begin{array}{l}\text { 燃料エンタルピ } \\
\text { (ミ燃料の許容限界 })\end{array}$ & $\begin{array}{l}\text { 原子炬起動時における制 } \\
\text { 御棒の異常な引抜き }\end{array}$ & ゼロ出力状態 (高温待機時)の解析のため，影響は軽微。 & $\mathrm{A}$ \\
\hline $\begin{array}{l}\text { 原子炉圧力 }(\leqq 9.48 \mathrm{MPa} \\
\text { [gage] })\end{array}$ & $\begin{array}{l}\text { 負荷の喪失(発電機負荷 } \\
\text { 遮断バイパス弁不作動) }\end{array}$ & $\begin{array}{l}\text { 主蒸気流量の増加で主蒸気遮断量が増加するため, 過渡時の原子 } \\
\text { 炉圧力が上昇することが考えられる。 }\end{array}$ & $\mathrm{C}$ \\
\hline
\end{tabular}

第 4 表＼cjkstart事故に対する概略評価結果 (BWR)

\begin{tabular}{|c|c|c|c|}
\hline $\begin{array}{l}\text { 評価項目 } \\
\text { (）内は判断基準 }\end{array}$ & $\begin{array}{l}\text { 判断基準に対して } \\
\text { 最も厳しい事象 }\end{array}$ & 出力向上の影響 & 分類 \\
\hline $\begin{array}{l}\text { 炉心冷却性能 } \\
\quad\left(\mathrm{PCT} \leqq 1200{ }^{\circ} \mathrm{C}\right) \\
(\mathrm{ECR} \leqq 15 \%)\end{array}$ & $\begin{array}{l}\text { LOCA } \\
\qquad \text { (ECCS 性能評価) }\end{array}$ & 崩壊熱が増加するため，PCT/ECR の上昇が考えられる。 & $\mathrm{C}$ \\
\hline $\begin{array}{l}\text { 燃料エンタルピ (ミ燃料 } \\
\text { エンタルピ制限值) }\end{array}$ & 制御棒落下 & $\begin{array}{l}\text { ゼロ出力状態 (冷温時および高温待機時)の解析のため, 影響は軽 } \\
\text { 微。 }\end{array}$ & $\mathrm{A}$ \\
\hline $\begin{array}{l}\text { 原子炉圧力 } \\
\quad(\leqq 10.34 \mathrm{MPa}[\text { gage }])\end{array}$ & $\begin{array}{l}\text { 原子炉冷却材ポンプの } \\
\text { 軸固着 }\end{array}$ & $\begin{array}{l}\text { 主蒸気流量の増加で主蒸気遮断量が増加するため, 事故時の原子 } \\
\text { 炉圧力が上昇することが考えられる。 }\end{array}$ & $\mathrm{C}$ \\
\hline $\begin{array}{l}\text { 格納容器内圧力 } \\
\quad(\leqq 310 \mathrm{kPa}[\text { gage }])\end{array}$ & $\begin{array}{l}\text { LOCA } \\
\qquad(\mathrm{PCV} \text { 健全性評価 })\end{array}$ & $\begin{array}{l}\text { LOCA 時の格納容器に放出されるエネルギーが増加するため, } \\
\text { 格納容器内圧力, 温度が上昇することが考えられる。 }\end{array}$ & $\mathrm{C}$ \\
\hline $\begin{array}{l}\text { 周辺公衆に対する線量 } \\
\quad(\leqq 5 \mathrm{mSv})\end{array}$ & $\begin{array}{l}\text { 放射性気体廃棄物処理施 } \\
\text { 設の破損 }\end{array}$ & $\begin{array}{l}\text { 燃料中の核分裂生成物蓄積量が出力向上割合に比例して増加する } \\
\text { が，現行評価において判断基準を十分下回っているので，判断基 } \\
\text { 準は満足。 }\end{array}$ & $\mathrm{B}$ \\
\hline $\begin{array}{l}\text { 格納容器内可燃性ガス濃 } \\
\text { 度 }(\leqq 4 \mathrm{vol} \% \text { [水素] } \\
\text { または } 5 \mathrm{vol} \% \text { [酸素]) }\end{array}$ & 可燃性ガスの発生 & $\begin{array}{l}\text { 核分裂生成物の炉内蓄積量の増加で格納容器内放射線が増加する } \\
\text { ため, 格納容器内水素および酸素濃度が増加することが考えられ } \\
\text { る。 }\end{array}$ & $\mathrm{C}$ \\
\hline
\end{tabular}


(b) 出力向上においても安全性は確保されるのか

次に, 出力向上の影響を定量的に確認する。分類 $\mathrm{A}$ および $\mathrm{B}$ の項目については, 概略評価の結果，判断基 準を満足することは容易に推測できるため，ここでは， 出力向上の影響を容易に推測できない分類 $\mathrm{C}$ の項目と して抽出された MCPR，原子炉圧力， PCT/ECR，格納 容器内圧力および格納容器内可燃性ガス濃度について出 力向上の影響を定量的に確認する。確認にあたっては, 判断基準に対して最も厳しい「負荷の喪失(発電機負荷遮 断バイパス弁不作動) 」および「LOCA」を対象に解析評価 を実施した。ここでは，現行の評価手法を用いた。

第 5 表に解析評価結果のまとめを，第 1,2 図におの おの「負荷の喪失 (発電機負荷遮断バイパス弁不作動) 」, $\lceil\mathrm{LOCA}$ (大破断)」の解析例を示す。解析例では，出力向 上前の解析結果も合わせてプロットしたが，「LOCA（大 破断)」では出力向上前後で水位, 圧力等の挙動は図上で はその差を識別できない程度である。

以上，注目すべき項目に対して，現行の評価手法を用 いて解析評価を実施した結果, 出力向上条件下でも判断 基準を満足することが示された。

\section{(3) PWR の評価結果}

(a) 出力向上において注目すべき項目は何か

代表 PWR プラントを対象に, 現行評価(出力向上前) の結果を参考に，安全評価の全事象を対象として，現行 手法をべースに評価項目ごとに出力向上に係る安全評価 への影響を概略評価する。概略評価の結果を第 6,7 表 に示す。概略評価結果は, 前述の出力向上の影響の程度 による分類で，以下のように整理することができる。

分類 $\mathrm{A}$ : 燃料中心温度, 燃料エンタルピ, 原子炬圧力, 原子炉格納容器圧力

分類 B：周辺公衆に対する線量, 可燃性ガス濃度 分類 C : PCT/ECR, 最小 DNBR

以上より, PWRの安全評価において出力向上時に注
第 5 表 解析評価のまとめ

\begin{tabular}{|c|c|c|c|}
\hline \multicolumn{2}{|c|}{$\begin{array}{c}\text { 評価項目 } \\
\text { （）内は判断基準 }\end{array}$} & 解析事象 & 解析值 \\
\hline \multirow{2}{*}{$\begin{array}{l}\text { 運 } \\
\text { 軽 } \\
\text { 異 } \\
\text { 常 } \\
\text { 過 } \\
\text { 滦 } \\
\text { 化 }\end{array}$} & $\begin{array}{l}\text { MCPR } \\
(\geqq 1.07)\end{array}$ & $\begin{array}{l}\text { 負荷の㳖失(発電 } \\
\text { 機負荷遮断バイ } \\
\text { パス弁不作動) }\end{array}$ & $\begin{array}{l}\Delta \mathrm{MCPR}: 0.32 \\
{[\mathrm{MCPR}=\text { 運転制限 }} \\
\mathrm{MCPR}-\Delta \mathrm{MCPR}]\end{array}$ \\
\hline & $\begin{array}{l}\text { 原子炉圧力 } \\
(\leqq 9.48 \mathrm{MPa} \\
{[\text { gage] })}\end{array}$ & $\begin{array}{l}\text { 負荷の变失(発電 } \\
\text { 機負荷遮断バイ } \\
\text { パス弁不作動) }\end{array}$ & 約8.05 MPa \\
\hline \multirow{3}{*}{$\begin{array}{l}\text { 事 } \\
\text { 故 }\end{array}$} & $\begin{array}{l}\text { 炉心冷却性能 } \\
\left(\mathrm{PCT} \leqq 1200^{\circ} \mathrm{C}\right) \\
(\mathrm{ECR} \leqq 15 \%)\end{array}$ & $\begin{array}{l}\text { LOCA } \\
\text { (ECCS 性能評 } \\
\text { 価) }\end{array}$ & $\begin{array}{l}\text { 大破断：約 } 587^{\circ} \mathrm{C} \\
\text { 中小破断：約 } 583^{\circ} \mathrm{C} \\
\mathrm{ECR} \text { : 極めて小さい }\end{array}$ \\
\hline & $\begin{array}{l}\text { 格納容器内圧力 } \\
(\leqq 310 \mathrm{kPa} \\
\text { [gage] })\end{array}$ & $\begin{array}{l}\text { LOCA } \\
\text { (PCV 健全性評 } \\
\text { 価) }\end{array}$ & 約 $254 \mathrm{kPa}$ \\
\hline & 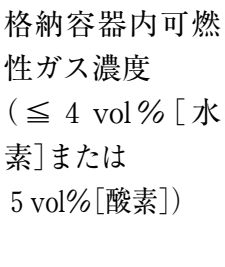 & $\begin{array}{l}\text { 可燃性ガスの発 } \\
\text { 生 }\end{array}$ & $\begin{array}{l}\text { 【水素濃度】 } \\
\text { 約3.4\% }(\mathrm{D} / \mathrm{W}), \\
\text { 約1.3\% }(\mathrm{S} / \mathrm{C}) \\
\text { 【酸素濃度】 } \\
\text { 約 } 4.4 \%(\mathrm{D} / \mathrm{W}) \text {, } \\
\text { 約 } 4.4 \%(\mathrm{~S} / \mathrm{C})\end{array}$ \\
\hline
\end{tabular}

D/W：ドライウェル， S/C：サプレッションチェンバ

目すべき項目は, 分類 C の PCT/ECR および最小 DNBR である。

(b) 出力向上においても安全性は確保されるのか

次に，出力向上の影響を定量的に確認した。分類 $\mathrm{A}$ および B の項目については，概略評価の結果，判断基 準を満足することは容易に推測できるため，ここでは， 出力向上の影響を容易に推測できない分類 C の項目と して抽出された PCT/ECR および最小 DNBR について 出力向上の影響を定量的に確認する。確認にあたって は，判断基準に対して最も厳しい「LOCA（ECCS 性能評 価)」および「原子炬冷却材ポンプの軸固着(最小 DNBR
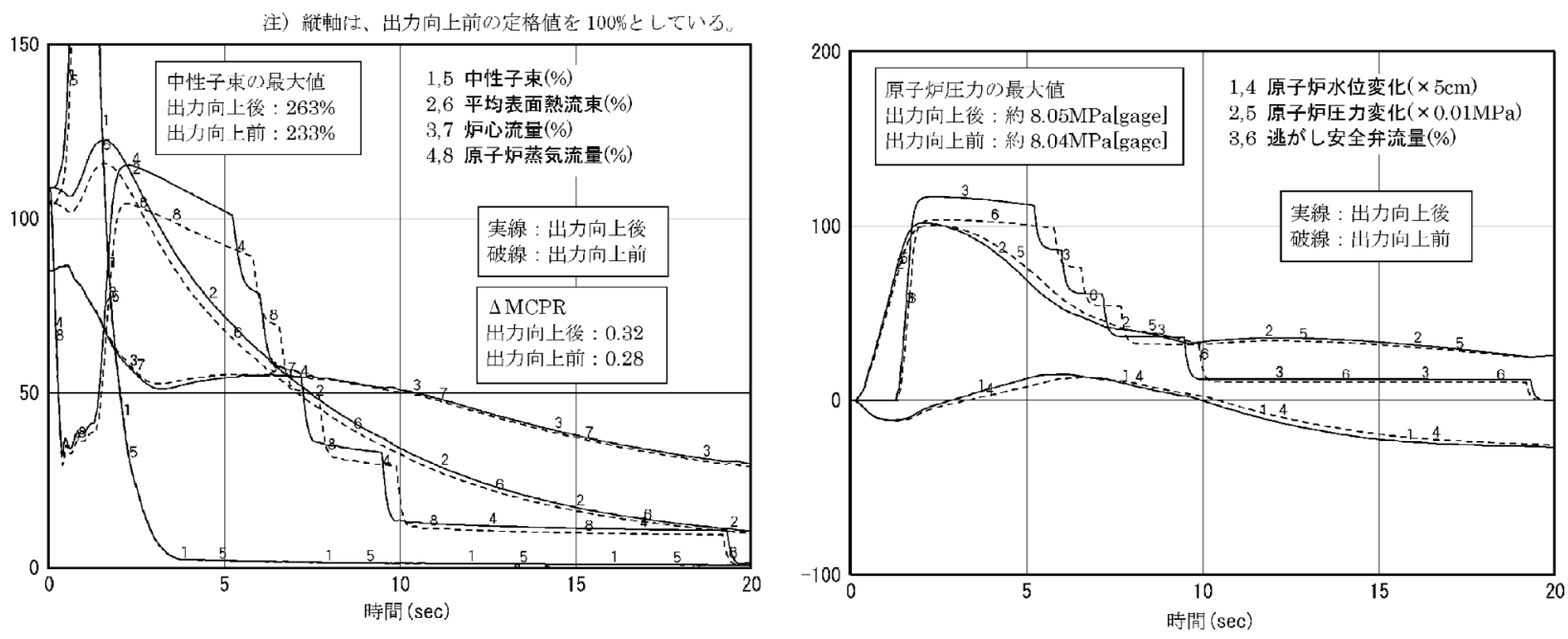

第 1 図負荷の喪失(発電機負荷遮断バイパス弁不作動)の解析例 (BWR) 

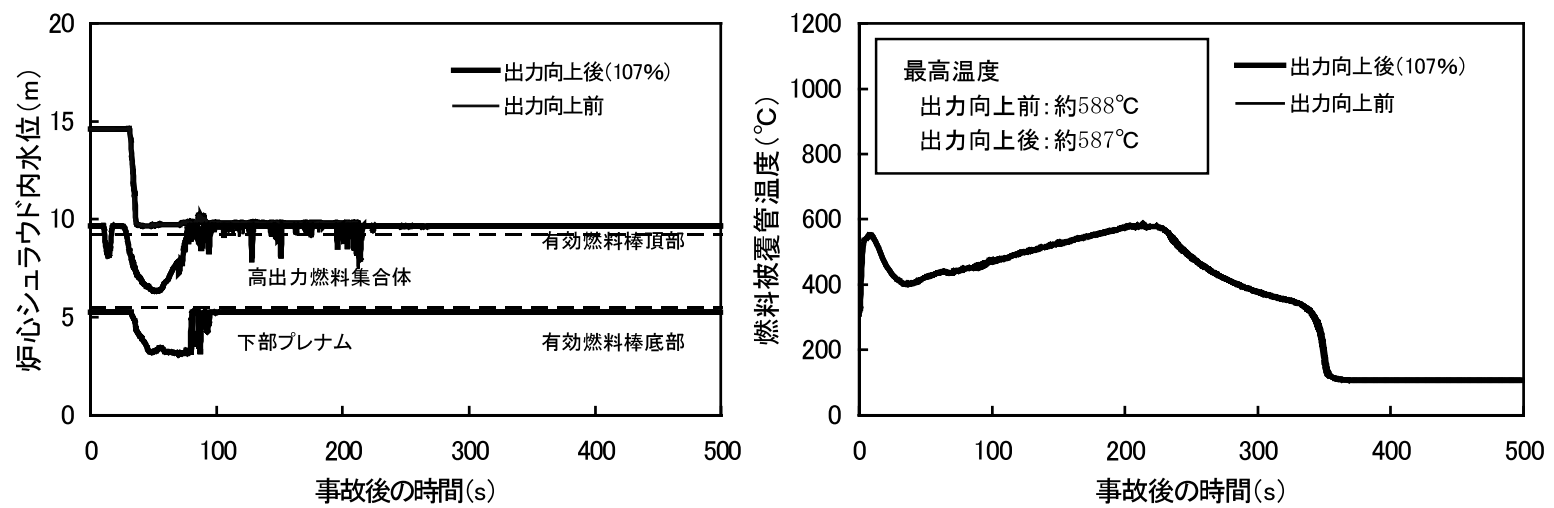

第 2 図 LOCA (大破断)の解析例 (BWR)

第 6 表 運転時の異常な過渡変化に対する概略評価結果 (PWR)

\begin{tabular}{|c|c|c|c|}
\hline $\begin{array}{l}\text { 評価項目 } \\
\text { (）内は判断基準 }\end{array}$ & $\begin{array}{l}\text { 判断基準に対して } \\
\text { 最も箃しい事象 }\end{array}$ & 出力向上の影響 & 分類 \\
\hline $\begin{array}{l}\text { 最小 DNBR } \\
\quad \text { （ 許容限界值） }\end{array}$ & $\begin{array}{l}\text { 出力運転中の制御棒の } \\
\text { 異常な引抜き }\end{array}$ & $\begin{array}{l}\text { 定格運転時最小 DNBR は低下し, それに伴って過渡時最小 DNBR } \\
\text { も低下。現行評価において判断基準を十分上回っているので, 出 } \\
\text { 力向上後も判断基準は満足される見通し。 }\end{array}$ & $\mathrm{C}$ \\
\hline $\begin{array}{l}\text { 燃料中心温度 } \\
\text { (<燃料ペレット溶融点) }\end{array}$ & $\begin{array}{l}\text { 出力運転中の制御棒の } \\
\text { 異常な引抜き }\end{array}$ & $\begin{array}{l}\text { 左記事象で対象としている線出力密度は, 実際の過渡時線出力密 } \\
\text { 度に十分に余裕を見达んだ值であり, 出力向上後も評価対象とな } \\
\text { る線出力密度は变更しないため, 出力向上の影響は軽微。 }\end{array}$ & $\mathrm{A}$ \\
\hline $\begin{array}{l}\text { 燃料エンタルピ } \\
\text { (@燃料の許容限界) }\end{array}$ & $\begin{array}{l}\text { 原子炉起動時における } \\
\text { 制御棒の異常な引抜き }\end{array}$ & 高温ゼロ出力からの解析であり, 出力向上の影響は軽微。 & $\mathrm{A}$ \\
\hline $\begin{array}{l}\text { 原子炉圧力 } \\
\quad(\leqq 18.88 \mathrm{MPa} \text { [gage] })\end{array}$ & 負荷の㳖失 & $\begin{array}{l}\text { 原子炉圧力の上昇が考えられるが, 過渡時原子炉圧力は加圧器安 } \\
\text { 全弁作動設定圧付近に留まるため, 出力向上の影響は軽微。 }\end{array}$ & $\mathrm{A}$ \\
\hline
\end{tabular}

第 7 表＼cjkstart事故に対する概略評価結果 (PWR)

\begin{tabular}{|c|c|c|c|c|}
\hline & $\begin{array}{l}\text { 評価項目 } \\
\text { （）内は判断基準 }\end{array}$ & $\begin{array}{l}\text { 判断基準に対して } \\
\text { 最も㛜しい事象 }\end{array}$ & 出力向上の影響 & 分類 \\
\hline 炉 & $\begin{array}{l}\operatorname{PCT}\left(\leqq 1,200^{\circ} \mathrm{C}\right) \\
\operatorname{ECR}(\leqq 15 \%)\end{array}$ & $\begin{array}{l}\text { LOCA } \\
\qquad(\mathrm{ECCS} \text { 性能評価) }\end{array}$ & 線出力密度および崩壊熱が増加するため, PCT/ECR が上昇。 & $\mathrm{C}$ \\
\hline $\begin{array}{l}\text { 冷 } \\
\text { 却 }\end{array}$ & $\begin{array}{l}\text { 最小 DNBR } \\
\text { ( } \geqq \text { 許容限界值) }\end{array}$ & $\begin{array}{l}\text { 原子炉冷却材ポンプの } \\
\text { 軸固着 }\end{array}$ & $\begin{array}{l}\text { 定格運転時最小 DNBR は低下し, それに伴って過渡時最小 DNBR } \\
\text { も低下。 }\end{array}$ & $\mathrm{C}$ \\
\hline & 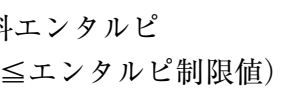 & $\begin{array}{l}\text { 制御棒飛び出し } \\
\quad \text { (高温ゼロ出力) }\end{array}$ & 高温ゼロ出力からの解析であり, 出力向上の影響は軽微。 & $\mathrm{A}$ \\
\hline & $\begin{array}{l}\text { 飞炉圧力 } \\
\leqq 20.59 \mathrm{MPa} \text { [gage] })\end{array}$ & 主給水管破断 & $\begin{array}{l}\text { 原子炉圧力の上昇が考えられるが, 過渡時原子炉圧力は加圧器安 } \\
\text { 全弁作動設定圧付近に留まるため, 出力向上の影響は軽微。 }\end{array}$ & $\mathrm{A}$ \\
\hline & $\begin{array}{l}\text { 内容器内圧力 } \\
\text { 最高使用圧力） }\end{array}$ & $\begin{array}{l}\text { LOCA } \\
\qquad \text { (CV 健全性評価) }\end{array}$ & $\begin{array}{l}\text { 炉心保有エネルギーおよび崩壊熱が増加するため, 事故時 CV 圧 } \\
\text { 力が上昇することが考えられるが, 出力向上に伴う CV 圧力への } \\
\text { 寄与は軽微。 }\end{array}$ & A \\
\hline & $\begin{array}{l}\text { 卫公衆に対する線量 } \\
\leqq 5 \mathrm{mSv})\end{array}$ & $\begin{array}{l}\text { LOCA } \\
\qquad(\text { 蒸気発生器伝熱管 } \\
\text { 破損 })\end{array}$ & $\begin{array}{l}\text { 核分裂生成物の炉内蓄積量および } 1 \text { 次冷却材中の核分裂生成物の } \\
\text { 濃度が出力向上割合にほぼ比して増加するが, 現行評価におい } \\
\text { て判断基準を十分下回っているので, 判断基準は満足。 }\end{array}$ & $\mathrm{B}$ \\
\hline & $\begin{array}{l}\text { 然性ガス濃度 } \\
\leqq 4 \mathrm{vol} \% \text { 水素] })\end{array}$ & 可燃性ガスの発生 & $\begin{array}{l}\text { 核分裂生成物の炉内蓄積量が出力向上割合に比例して増加し, 格 } \\
\text { 納容器内放射線が増加するため, 格納容器内水素濃度は増加する } \\
\text { ことが考えられるが, 現行評価において判断基準を十分下回って } \\
\text { いるので, 判断基準は満足。 }\end{array}$ & $\mathrm{B}$ \\
\hline
\end{tabular}


評価)」を対象に解析評価を実施した。ここでは，将来， 出力向上を申請する場合に使用すると予想される改良手 法(統計的安全評価手法および核熱結合手法)を用いた。 これらの手法は，米国ではすでに開発済みであり，国内 においても開発はほぼ完了している。統計的安全評価手 法に関する日本原子力学会標準が2008年度中に発刊予定 である。

a) LOCA

LOCA の ECCS 性能評価は, 最適評価コード (MCOBRA/TRAC)を用いた統計的安全評価手法(順序 統計法)による評価を実施した。第 3 図に，その解析例 を示すが，統計的安全評価手法を用いて評価すると， $\mathrm{PCT} / \mathrm{ECR}$ は約 $950^{\circ} \mathrm{C} /$ 約 $1 \%$ となり, 出力向上条件下で も判断基準を十分に満足する結果となった。

b）原子炉冷却材ポンプの軸固着

原子炬冷却材ポンプの軸固着の最小 DNBR 評価は, 核熱結合評価手法を適用したSPARKLEコードを用い て評価を実施した。第 4 図に，その解析例を示すが，核 熱結合手法により出力向上時の最小 DNBR を評価する と, 1 次冷却材温度上昇に伴う減速材密度フィードバッ ク効果が急激に添加されることにより過渡時の炉心出力 が早期に緩和され, 出力向上条件下でも, DNBR 許容 限界值を満足することが確認された。

以上，注目すべき項目に対して，改良手法を用いて解 析評価を実施した結果, 出力向上条件下でも判断基準を 満足することが示された。

（4）「安全評価への影響」のまとめ

$\lceil[\mathrm{a}]$ 安全評価に係る項目」のうち，安全評価審査指針 に定められた評価事象を対象に，BWR/PWR 代表プラ ントにおける出力向上に係る影響を評価・考察した結果 を以下に示す。

・概略評価により, 出力向上を図る場合に安全評価に おいて注目すべき項目を抽出した。

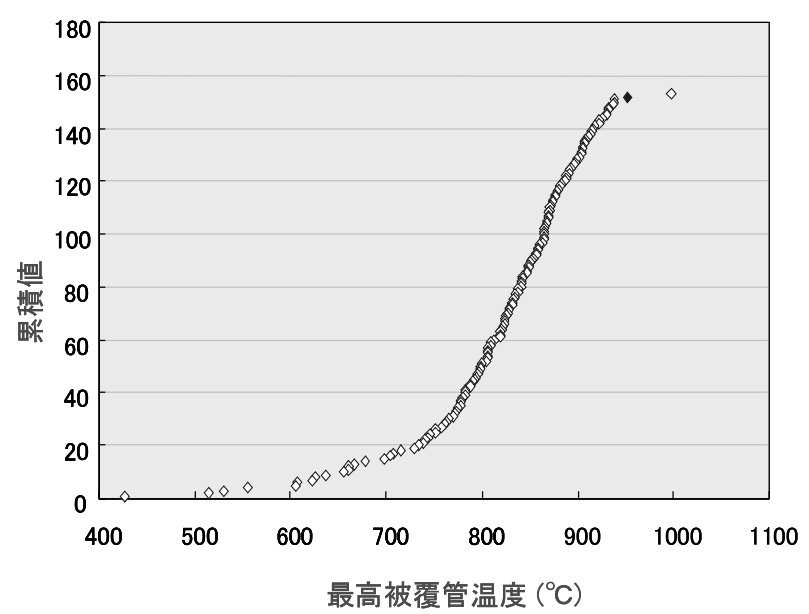

第 3 図出力向上における「LOCA (ECCS 性能評価)」の解析例 （国内 PWR 代表 3 ループプラント， MCOBRA/TRAC + 統計的安全評価手法)
・注目すべき項目に対して，判断基準に対して最も厳 しい事象を対象に解析評価を実施した結果，判断基 準を満足することが確認された。

・ BWR 5 代表プラントは約 $7 \%$, PWR 代表 3 ループ プラントは約 $9 \%$ の出力向上割合で評価した結果, 安全評価の判断基準を逸脱することはなく, 出力向 上の安全性は確保される見通しが得られた。

・ただし, 将来, 実機において出力向上を図る場合は, 個別プラントごとに出力向上の安全性を確認する必 要がある。

・出力向上にあたっては，最新の研究成果を反映した 解析手法を採用することが合理的である。また，出 力向上は，それに適合する改良燃料の開発などの新 技術を導入する契機となる。

\section{3. 設備への影響評価}

出力向上に伴い安全上評価すべき項目は， II-1節で述 ベたとおり，「[a]安全評価に係る項目」と「[b]設備への 影響を評価すべき項目」に分類される。

$\lceil[\mathrm{b}]$ 設備への影響を評価すべき項目」は，出力向上に よる影響はどのようなことが考えられるか，また，その 影響はどのように評価・対応できるか，について検討し た結果，設計，保全管理，運用管理を適切に実施すれば プラントの安全性は保たれると判断された。

本節では，「[b]設備への影響を評価すべき項目」のう ち, 注目事象として中性子照射量の増加による脆化への 影響，流れ誘起振動に起因した振動疲労への影響，およ び流れ加速型腐食による配管減肉への影響について述べ る。

（1）中性子照射量の増加による脆化への影響

中性子照射によって原子炉圧力容器の破壊勒性が低下 する照射脆化について，電気技術規程 JEAC 4201-2004 「原子炉構造材の監視試験方法」に規定される監視試験を 実施し，勒性の低下を監視している。また，電気技術規

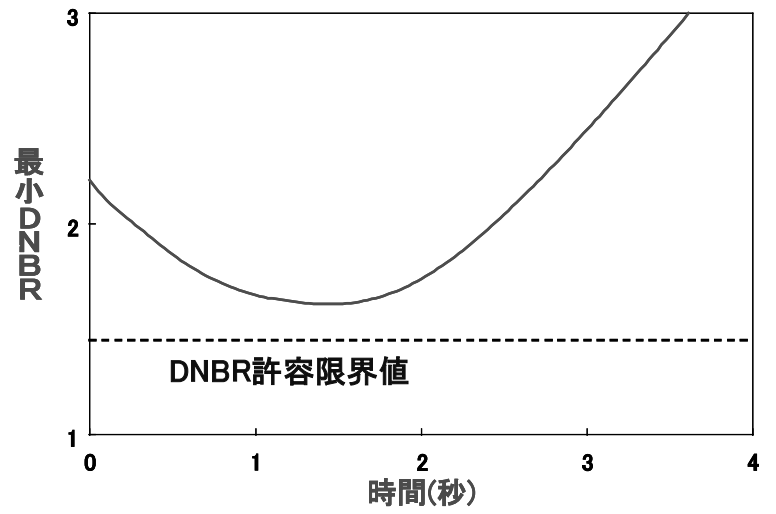

第 4 図 出力向上における「原子炬冷却材ポンプの軸固着 (最小 DNBR 評価) 」の解析例 （国内 PWR 代表 3 ループプラント， 核熱結合評価手法) 
程 JEAC 4206-2004「原子力発電所用機器に対する破壊 勒性の確認試験方法」に従って，材料の関連温度 (RTNDT) に基づく原子炉冷却材の圧力・温度制限を設 けるとともに，上部棚吸収エネルギー(USE)の低下に対 する評価などを実施し, 原子炉圧力容器の健全性を確認 している。

原子炉の出力向上時には炉心中性子束が増加するが, この出力向上後の条件でも前述の評価方法は適用でき る。したがって, 出力向上後の照射時間を考慮した原子 炉圧力容器への中性子照射量を求め, 材料の関連温度お よび上部棚吸収エネルギーなどの評価を行うことができ る。これらの評価結果を適切に保全管理に反映すること により, 原子炉圧力容器の健全性を確保できるように管 理することができる。

\section{（2）流れ誘起振動に起因した影響}

(a) 蒸気乾燥器および主蒸気逃がし安全弁の振動

出力向上により主蒸気の流速が増加するため, 流れ誘 起振動(Flow Induced Vibration:FIV)の発生が考えら れる。

米国の $\mathrm{E}$ 型出力向上 $(17.8 \% \mathrm{Up})$ プラント (Quad Citis : BWR)において, 蒸気乾燥器の振動疲労損傷や主 蒸気配管に設置されている逃がし安全弁の駆動機構の損 傷が経験されている。原因調查の結果, 出力向上に伴い 主蒸気の流速が増加した主蒸気配管内で主蒸気の流れに 起因した音響共鳴現象が発生し，この音響振動が主原因 であることが確認された。

音響共鳴現象の発生メカニズムは, 主蒸気配管に設置 された逃がし安全弁の管台分岐部を高流速の蒸気流が通 過する際に，管台分岐部で発生する渦の発生周波数が管 台の形状寸法から決まる音響固有振動数に一致して音響 共鳴が発生するというものである。音響共鳴の発生メカ ニズム゙)を第 5 図に示す。

(b) 音響共鳴現象に関する検討

音響共鳴現象が分岐管部で発生し始める蒸気流速の評 価式から, 本損傷事例が発生した米国出力向上プラント での主蒸気流速条件での音響共鳴発生の有無を評価し た。この結果, 損傷発生プラントの主蒸気配管形状から

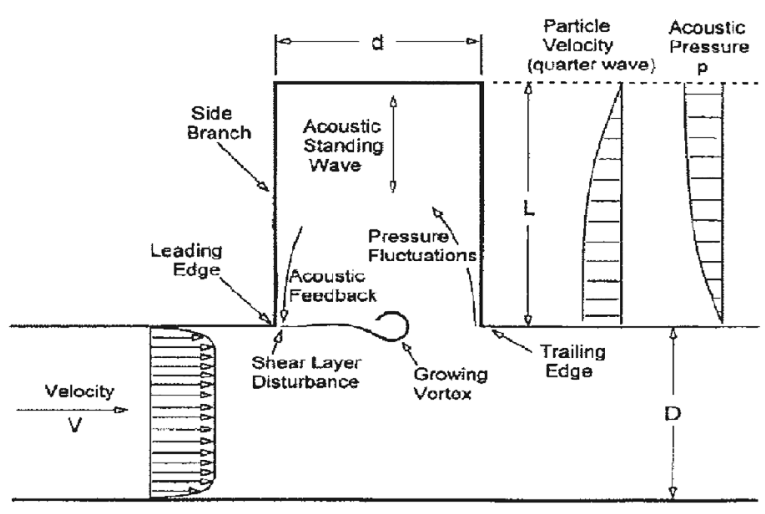

第 5 図 主蒸気の流れによる音響共鳴の発生メカニズム
決まる音響固有振動数と, 他プラントと比較して際立っ て大きい主蒸気流速条件から音響共鳴が発生することが わかった。

また，本損傷事象が発生していない米国 E 型出力向 上プラントの主蒸気流速は, Quad Citis より小さく, ま た，標準的な国内プラント (BWR 5 )での $\mathrm{E}$ 型出力向上 時のモデル評価でも音響共鳴の発生の可能性は低いこと がわかった。第 8 表にQuad Citis と標準的な国内プラ ント (BWR 5 )の主蒸気流速および音響共鳴の開始流速 の比較を示す。

なお，当該プラントは，共鳴の発生防止対策として， 逃がし安全弁管台分岐部に枝管を設置し，分岐管台部の 有効長さを増加, 音響固有振動数を低下させることに よって出力向上運転における共鳴発生の防止を図ってい る。

以上のことから, 今後, 個々のプラントが出力向上を 実施する際には, 出力向上条件での流れ誘起振動に関す る評価や保全管理を適切に実施すれば，機器損傷の未然 防止等の対応は可能であると考えられる。

\section{（3）配管の流れ加速型腐食現象への影響}

原子力プラントの炭素鋼配管では, オリフィス下流, エルボ，曲げ管， T管，レデューサなどの偏流部におい て，腐食(コロージョン)が流れの乱れによる物質移動の 増大により静水中の腐食を超えて加速される流れ加速型 腐食(Flow Accelerated Corrosion: FAC)が発生する。 この FAC 現象は，プラント配管劣化の主要なモードの 一つであり配管損傷につながりうるため, 肉厚管理をす ることが必要である。

本稿では代表プラントとして, 国内 BWR プラントの 58\%を占める BWR 5 を選定し, 一般的にプラント性能 範囲内で達成されるストレッチ ( $\mathrm{S}$ 型) 出力向上に相当す るレベルとして $5 \%$, 大規模な設備改造を伴う設備拡張

第 8 表 Quad Citis と国内 BWR 5 の比較

\begin{tabular}{|l|c|c|}
\hline & $\begin{array}{c}\text { Quad Citis } \\
(17.8 \% \text { 出力 Up })\end{array}$ & $\begin{array}{c}\text { 国内 BWR 5 } \\
(20 \% \text { 出力 Up 例 })\end{array}$ \\
\hline \begin{tabular}{l} 
主蒸気流速 $(\mathrm{A})$ \\
\hline $\begin{array}{l}\text { 音響共鳴開始 } \\
\text { 流速 }{ }^{*}(\mathrm{~B})\end{array}$
\end{tabular} & 約 $30 \sim 40(\mathrm{~m} / \mathrm{s})$ & 約 $53(\mathrm{~m} / \mathrm{s})$ \\
\hline 流速比 $(\mathrm{A}) /(\mathrm{B})$ & $1.5 \sim 2.1$ & 約 $58(\mathrm{~m} / \mathrm{s})$ \\
\hline 評 価 & $\begin{array}{l}\text { 音響共鳴が発生 } \\
\text { し得る }\end{array}$ & $\begin{array}{l}\text { 音響共鳴発生の } \\
\text { 可能性は低い }\end{array}$ \\
\hline
\end{tabular}

* : 音響共鳴開始流速 (分岐管の形状寸法から決まる流速) $=f(d+r) / 1.2 \times S t$

$f: 1 / 4$ 波長の音響共鳴周波数 $f=C /(4 \times L)$

$C$ : 主蒸気配管内蒸気の音速

$L:$ 分岐管の長さ, $d:$ 分岐管直径

$r$ : 分岐管入口部の曲率半径

$S t:$ ピーク共鳴に対応するストローハル数 $(=0.56)$

1.2 : 係数 (音響共鳴のピーク点流速より $20 \%$ 低い流速を音響 共鳴開始点と定義するため設定) 
型 ( $\mathrm{E}$ 型) 出力向上に相当するレベルとして $15 \%$ 想定し て, FACによる減肉率がどのような傾向で変化するか, また，FACによる配管減肉の管理計画へどの程度影響 するかを調べた。評価では，BWRの配管減肉管理に関 する技術規格 ${ }^{5}$ において最短寿命が 20 年以下とされてい る系統, さらに減肉率が比較的高いとされている箇所に ついて，国内 BWR 5 プラントにおける出力向上前後の プロセス量の変化を参考にして，FACによる配管減肉 の変化 (余寿命や減肉率の変化)の傾向をつかむための概 略評価を実施した。

減肉率を算定するための評価コードとしては，内容が 公開されており, 定量的に評価が可能なものとして WATHEC コード6) を用いた。本コードはおおむね保守 的な推定值を与えるが，計算值と実測值の比較において バラツキが見られる。しかし，出力向上前後における配 管減肉の変化の傾向を見るのであれば，十分適用できる と考える。

評価結果を第 6 図に示す。ここで系統 No. は，規格 ${ }^{5)}$ に記載されている系統 No. と対応している。 $5 \%$ 出力向 上のケースでは，最短寿命が10年を下回る系統は見られ ず，ほとんどの系統で出力向上前の寿命に対する変化率 (RL) は大きくない (減肉率は $150^{\circ} \mathrm{C}$ 付近でピークを持つ ため, 温度条件によっては寿命が長くなる系統も多い) という結果が得られた。15\%出力向上のケースでは, ター ビンから給水加熱器に至る抽気系の一部(No. 10-2，122)で寿命がやや短くなる傾向が見られたものの，寿命は 10年程度であり, 従来の保全管理方法で対応できるレベ ルであった。また低合金鋼やステンレス鋼などの対策材 が使用されているプラントでは，寿命低下が大幅に軽減 される。その他の箇所については $5 \%$ 出力向上と同様 に，寿命の低下がわずかであるか，あるいはむしろ長く なる系統が多く，影響は小さいものであった。

以上のように，FACについては出力向上による配管 減肉管理計画への影響は小さく, 従来の保全管理方法を
適切に実施すれば対応が可能な見通しである。

(山口 彰)

\section{III. まとめと提言}

\section{MU 型出力向上に関する検討結果と提言}

$\mathrm{MU}$ 型原子炉出力向上を目的とした超音波流量計の計 測不確かさについての検討結果を以下にまとめるととも に提言を行う。

- Crossflow 型, External 型については, 実機レイノ ルズ数付近での試験により，高レイノルズ数への外 挿性を評価することを推奨する。Chordal 型につい ては, 外挿性が比較的高いと判断される。

・本検討結果を参考に, 必要に応じて高レイノルズ数 試験と組み合わせることで，MU 型原子炬出力向上 は技術的に可能である。なお，実機適用に当たって は，「超音波流量計に関する技術検討評価」最終報告 書 ${ }^{7)}$ 参考に個別の評価を行い, 安全審査によって 判断を行う必要がある。

・より安全な出力向上を目指し, (1)不確かさ評価の標 準的手法の確立，(2)高レイノルズ数流量試験装置 ${ }^{2}$ による研究の推進, (3)新型流速分布式超音波流量計 ${ }^{3)}$ の開発などを推進することが重要である。

- 原子力安全委員会の ECCS 性能評価指針等の合理 的な改定を検討する必要がある。（木倉宏成）

\section{2. $\mathrm{S}$ 型, $\mathrm{E}$ 型出力向上に関する検討結果と提言} 原子力発電プラントにおいて，原子炉出力を増加させ ることによって電気出力を増やす出力向上は，欧米では すでに約30年ほど前から取り組まれ，運転年数30年以上 のプラントから最近のプラントにわたって，延べ約 160 件に及ぶ多数の実績がある。

これらの欧米における出力向上の状況に関する調查・ 検討結果を参考に，我が国における出力向上に際してプ

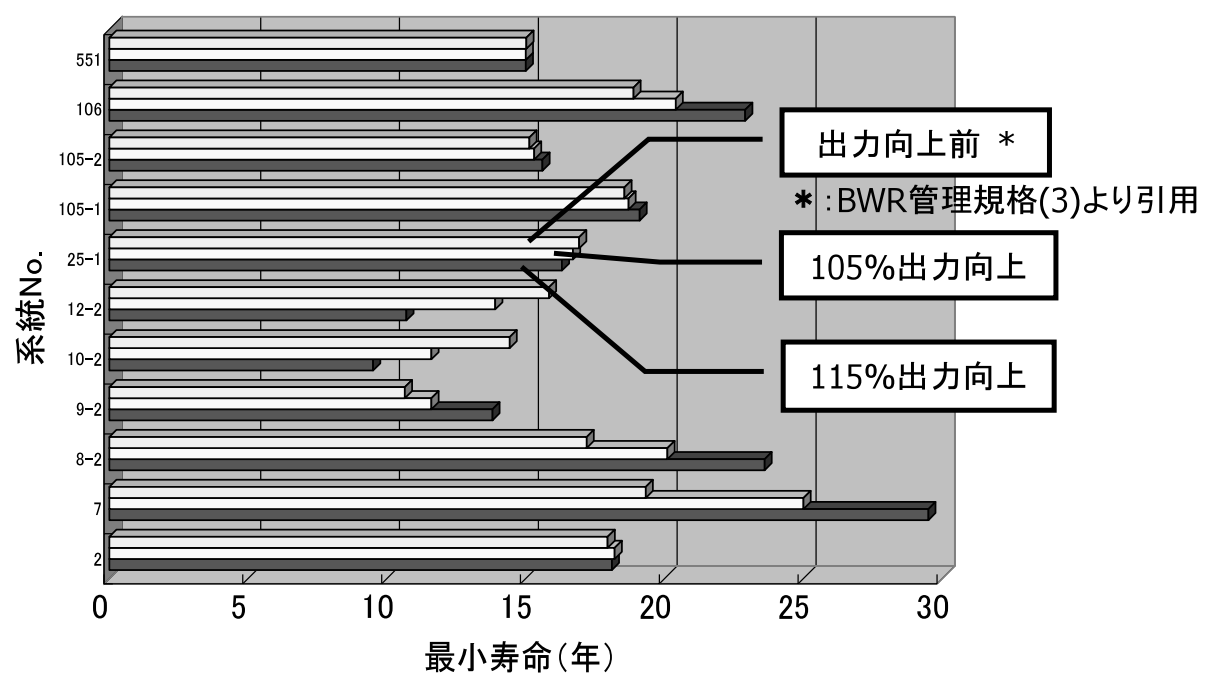

第 6 図 BWR プラントにおける FAC に対する出力向上の影響評価の例 
ラントへの影響検討を行い, 安全性確保の観点から安全 上評価すべき項目の検討および評価を実施した。

安全評価に係る項目は, 出力向上の評価条件が評価 コード等の適用範囲内であれば，現行の評価方法および 判断基準を適用することが可能である。

出力向上に係る安全評価への影響について, 出力向上 時に注目すべき項目の解析評価・考察を実施した結果， 判断基準を逸脱する項目はなく, 安全性は確保されると の見通しを得た。

設備への影響を評価すべき項目について検討した結 果, 設計，保全管理，または運用管理で対応することが 可能であり，適切に対応すれば，プラントの安全性は保 たれる。

以上の結果，我が国においても現在の知見と技術に基 づき技術的に適切に対応すれば，十分な安全性を確保し た出力向上が実施可能であると考える。環境問題などを 考慮すれば，安全を確保することを大前提とし，積極的 な原子炉出力向上が望まれる。

原子炬出力向上にあたっては, 本報告書 ${ }^{8}$ の内容を参 考に, 個別のプラントごとに原子炉出力向上条件におけ る評価を行い, 安全性が確保されることを確認していく ことが必要である。同様に, 原子炬出力向上による設備 影響については，個別のプラントごとに評価を実施し， 設計や保全管理で適切に対応していくことが重要であ る。また, 欧米での原子炉出力向上実績や運転経験など を反映し, 安全な原子炉出力向上が可能となるよう, 常 に最新知見を取り入れていくことが重要である。

さらに将来にむけて，安全かつ合理的に，より大幅な 原子炉出力向上を目指すため, 次の点が重要である。

* 安全評価手法の高度化を推進すること

* 新しい燃料の開発研究・導入を推進すること また，リスク情報の活用が推進されていくことを期待す る。

(岡本孝司)

\section{N ． 原子炉出力向上への期待}

前述の研究成果をとりまとめた報告書 ${ }^{7,8)}$ の内容に対し て，専門家の方々からの評価が寄稿された。以下にその 内容を示す。

\section{1. 研究成果の活用と期待}

欧米ではすでに多くの原子力発電プラントで出力向上 が実施されているが，それによって安全性が本質的に損 なわれるような事象は経験されていない。許認可上も， 出力向上に対して特別な規制は設けられておらず，リス ク評価の観点からも出力向上によるリスク増加量は小さ いということである。これらの実績から，わが国におい ても出力向上は可能と考えられるが，リスク増加に敏感 に反応し，より保守的な立場をとる傾向のあるわが国の
状況に鑑みれば，実プラントでの実施の際，より入念な 準備作業が必要になると予想される。リスク情報の活用 は，この報告 ${ }^{8}$ でも今後の課題の一つとして上げられて おり，規制の側でこれをうまく活用すれば国民の福祉の 向上につながると考えられる。

出力向上の方策としては, 測定精度改善 (MU) 型, ス トレッチ $(\mathrm{S})$ 型，設備拡張 $(\mathrm{E})$ 型の 3 つのタイプが考え られている。MU 型は，超音波流量計の計測誤差を現状 の $2 \%$ から, 例えば $0.5 \% に$ 減少して出力向上を図るも ので, 計測誤差 $0.5 \%$ という高精度が要求されることか ら, 当然, 流量計校正試験では極めて高い精度が要求さ れる。これに関しては，わが国には産業技術総合研究所 の新校正試験装置がある。これは高レイノルズ数までの 流量計の校正が可能な世界唯一の試験装置だということ であり，これを活用して信頼できるデー夕を提供してい ただきたい。

安全上評価すべき項目については，現行 BWR および PWR の代表プラントを対象に，設置許可申請書添付書 類記載事項をもとに， $\mathrm{S}$ 型および $\mathrm{E}$ 型の炉出力向上によ り評価すべき項目を網羅的に抽出し，それらの項目を安 全評価に係る項目と設備への影響を評価すべき項目とに 分類し，それぞれの項目について解析評価している。安 全評価では現行の判断基準を適用し，現行設備が判断基 準を満たさない場合には設備仕様の変更で対応するとし ている。ここで示された安全評価結果は, 現行代表プラ ントの炉心・燃料の設計および運転管理を前提としてお り，実プラントでの実施に際しては，個別プラントの特 性や運転管理を反映した安全評価を行うべきことはいう までもないことであるが，この報告書 ${ }^{8}$ で示された考え 方，手法およびその結果が大いに参考になる。また，安 全評価手法の高度化に関しては，原子力学会標準委員会 で検討中の統計的安全評価手法などが活用できよう。

設備への影響に関しては, 原子炉圧力容器の中性子照 射脆化の進行, BWR 蒸気乾燥器および主蒸気逃がし弁 の振動並びに配管減肉について評価している。これらの 事象の判断基準の根拠となる実測デー夕には，例えば配 管滅肉デー夕などのように，かなりのばらつきがあるも のがある。これは多くのパラメータの影響が把握されな いまま含まれているためであろう。これらのパラメータ の影響について理論的に考察し，あるいは条件の明らか な実測データを取得して，詳細に分析し，整理すれば， 判断基準はさらに合理的なものになるのではないか。こ の点に関し，統一された手法に従って個別プラントにお いて，実測デー夕を取得し，共通の知見として活用する ことができればよいと思う。

これらの検討評価により, 特別専門委員会では, (1)MU 型の出力向上は可能であり，その際，ょり信頼性の高い 流量計の検証と指針の合理的な改定が必要であること， (2) $\mathrm{S}$ 型および $\mathrm{E}$ 型の出力向上については，代表プラント 
の解析により十分な見通しが得られたこと，実プラント での実施においては現行の安全審査体系で個別プラント ごとに厳格に審査すれば十分であること，また，配管減 肉管理などの運転・保守管理を適切に行うべきこと，な どの結果をまとめている。今後の課題としては, 安全評 価手法の高度化, 新しい燃料の導入およびリスク情報の 活用の推進を挙げている。出力上昇量20～30\%となる と, 新しい燃料の導入が必要となると考えられるが，そ のメリットは大きいので, 今後, なんらかの形でそのた めの検討を進める必要がある。リスク情報の活用につい ては前述の通りである。

この特別専門委員会報告 ${ }^{7,8}$ は，原子炉出力向上の技術 的側面を総合的に検討評価し，わが国の代表プラントに おける出力向上の可能性を示した点で, 大いに評価でき る。この成果を踏まえて, 近い将来, わが国の実プラン トにおいて出力向上が実施されることを期待する。わが 国においては, 出力向上のほか, 高燃焼度燃料や MOX 燃料, 濃縮度 $5 \%$ 超燃料の使用, 定期検査期間延長など 様々な計画がある。それぞれの計画を実施する際，どの ような手順で, どのようなスケジュールで進めるかにつ いて, 研究開発に要する期間, 安全規制の要求, コスト, 社会的受容性などを考慮して総合的に戦略を立てる必要 がある。また，その際，国，民間企業，研究機関および 大学の間の適切な役割分担のもとに作業を進めるべきで あることはいうまでもない。

$$
\text { (三島嘉一郎) }
$$

\section{2. 総合的視点から一今後の展開について}

原子炬出力向上には, 軽水炉炉心燃料設計を始め, 安 全設計, 系統機器設計, 計測制御設計などのシステム設 計に関する事項を再検討，評価する必要がある。また， 設計・建設段階に加え，これまでの運転・保守の実績や 最新研究成果などを踏まえて, 材料劣化の加速, 水化学 との相互作用等に基づき, 保全, 高経年化などの観点か ら，軽水炉の運用に関する検討評価が必要である。

原子炉出力向上は，設計と運用という時空間にわたる 軽水炉技術全般に係わり，最新の知見を踏まえて出力向 上条件でそれらを見直す機会となる。このようなシステ マティックな検討評価は, 次世代軽水炉の設計開発にス ムースにつながっていくであろうことが予想されるもの であり，軽水炉技術の維持・発展という意味で重要な位 置を占めることになるであろう。今回の特別専門委員会 の成果が次世代軽水炉につながり，世界標準という形で 実を結んでいくことを願っている。

今回の特別専門委員会の活動は, 産官学が学会という 場をうまく活用した良い例といえよう。今回の報告書8) の内容をみると, 原子炉出力向上の安全性評価, 設備設 計/保全/運用への影響評価，さらにはリスク評価など， 多岐にわたる検討が行われており，その結果として総合
的な評価手法がきちんと提示されている。特に，原子炉 出力向上を実施するに当たり, 安全上評価すべき事項 を, 先達の知恵が集約されている安全設計審査指針や設 置変更許可申請書の記載事項を参照しながら専門家の思 考シミュレーションを通じて網羅的に抽出し，どのよう な評価方法と判断基準を適用すればよいか, 正確かつ明 確に示している点は評価に值する。原子炉出力向上の技 術評価のベースとなるものと評価する。

前述のように, 軽水炉技術は, 多くの技術から成り立っ ている総合技術である。それらの各種技術のうち, 高経 年化と燃料については，学会等の場をうまく利用して， この分野のこれまでの経緯や背景を明確にしつつ，今 後, どのような技術課題にどう取り組んでいけばよいか を明確にした「技術戦略マップ」が策定されている。今 後, その他の技術についても順次, 技術戦略マップやロー ドマップが策定されていくものと期待している。原子炉 出力向上に関する技術体系は今後，これら各技術分野の ロードマップに組み达まれ，協調していく必要があると 思われる。

高経年化や保全技術の観点からは，原子炬出力向上に 伴い, 中性子束やプロセス状態值 (圧力, 温度, 流量 [流 速])などの条件が変わるところをどのようにマネージし ていくかが課題である。個々の事象ごとには，十分管理 が可能であると考えられるが，技術全体として俯瞰的に 見てマネージしていくセンスも必要であろう。米国が 80 年運転の準備を戦略的に検討し始めているが，原子炉出 力向上と運転期間の延長を組み合わせた場合を想定した 制度的あるいは技術的な検討も必要とされている。

炉心燃料高度化の観点からは，多くの課題が議論され るべきである。例えば，トピカルレポートという制度を うまく活かしながら新しい燃料の導入に取り組んでいく 必要がある。BWRの $10 \times 10$ 燃料, PWRの新しい被覆 管の開発，さらには炉心燃料の解析技術の高度化などに 取り組んでいく必要がある。

原子炉出力向上を総合的に評価する手法としてリスク 評価があげられる。今回の特別専門委員会の報告書の中 でもリスク評価が取り上げられ，原子炉出力向上による リスク増は極めて小さいことが示されている。リスクと いうものをきちんと提示し，説明責任を果たしていくこ とも必要である。

以上, 今回の特別専門委員会報告書を読んで重要と考 えられる事項について述べさせていただいた。

\section{（関村直人）}

\section{一参 考文 献一}

1) NRC Regulatory Issue Summary 2007-24.

2) H. Sato,N. Furuichi,Y. Terao,M. Takamoto, "Uncertainty examination of new water flow calibration facility for nuclear power application," Proc. 2006 ASME Joint U. S. 
-European Fluids Engineering Summer Meeting, Florida, USA, July 17-20, 2006, \#98500, (2006).

3) M. Mori, Y. Takeda, T. Taishi, N. Furuichi, M. Aritomi, H. Kikura, "Development of a Novel Flow Measuring System using Ultrasonic Velocity Profile Measurement”, Exp. Fluids, 32〔2〕, 153-160(2002).

4) D. S. Weaver, G. O. MacLeod, Entrance Port Rounding Effects on Acoustic Resonance in Safety Relief Valves, PVP-Vol. 389, Flow Induced Vibration-1999, ASME, (1999).

5）発電用原子力設備規格 沸騰水型配管減肉管理に関する 技術規格 JSME S NH1-2006.

6) W. Kastner, R. Riedle, Empirisches Modell zur Berechung von Materialabtagen durch Erosionskorrosion, VGB-Kraftwerkstechnik 66, 12, 1171-1178(1986).

7）「超音波流量計に関する技術検討評価」最終報告書，原子 力学会「原子炬出力向上に関する技術検討評価」特別専門 委員会, 平成19年10月.

8）「原子炬出力向上の安全性に関する技術検討評価」最終報 告書，原子力学会「原子炬出力向上に関する技術検討評 価」特別専門委員会, 平成19年10月.

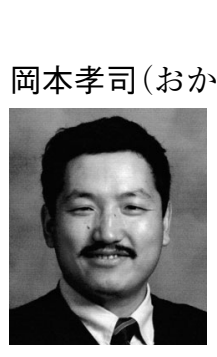

木倉宏成 (きくら・ひろしげ)

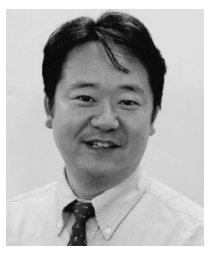

東京工業大学

(専門/関心分野) 原子炉熱流動, 熱流体計 測工学など

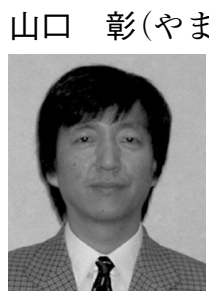

学

(専門/関心分野) 原子炉熱流動，可視化環 境学など

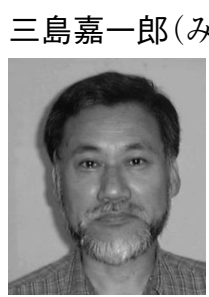

(専門/関心分野) 原子炉熱流動, 原子炬工 学など

関村直人（せきむら・なおと）

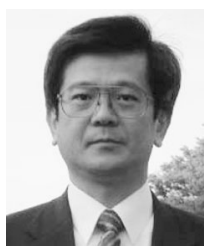

東京大学

(専門/関心分野) システム保全学，原子力 材料, 材料・環境相互作用など 